\title{
BMJ Open What interventions increase commuter cycling? A systematic review
}

\author{
Glenn Stewart, Nana Kwame Anokye, Subhash Pokhrel
}

To cite: Stewart G, Anokye NK, Pokhrel S. What interventions increase commuter cycling? A systematic review. BMJ Open 2015;5:e007945.

doi:10.1136/bmjopen-2015007945

\section{- Prepublication history and additional material is available. To view please visit the journal (http://dx.doi.org/ 10.1136/bmjopen-2015- 007945).}

Received 13 February 2015

Revised 11 July 2015

Accepted 20 July 2015

CrossMark

Health Economics Research Group (HERG), Institute of Environment, Health and Societies, Brunel University London, Uxbridge, UK

Correspondence to Glenn Stewart;

Glenn.Stewart@brunel.ac.uk

\section{ABSTRACT}

Objective: To identify interventions that will increase commuter cycling.

Setting: All settings where commuter cycling might take place.

Participants: Adults (aged 18+) in any country. Interventions: Individual, group or environmental interventions including policies and infrastructure.

Primary and secondary outcome measures: A wide range of 'changes in commuter cycling' indicators, including frequency of cycling, change in workforce commuting mode, change in commuting population transport mode, use of infrastructure by defined populations and population modal shift.

Results: 12 studies from 6 countries $(6$ from the UK, 2 from Australia, 1 each from Sweden, Ireland, New Zealand and the USA) met the inclusion criteria. Of those, 2 studies were randomised control trials and the remainder preintervention and postintervention studies. The majority of studies $(n=7)$ evaluated individualbased or group-based interventions and the rest environmental interventions. Individual-based or groupbased interventions in 6/7 studies were found to increase commuter cycling of which the effect was significant in only $3 / 6$ studies. Environmental interventions, however, had small but positive effects in much larger but more difficult to define populations. Almost all studies had substantial loss to follow-up.

Conclusions: Despite commuter cycling prevalence varying widely between countries, robust evidence of what interventions will increase commuter cycling in low cycling prevalence nations is sparse. Wider environmental interventions that make cycling conducive appear to reach out to hard to define but larger populations. This could mean that environmental interventions, despite their small positive effects, have greater public health significance than individual-based or group-based measures because those interventions encourage a larger number of people to integrate physical activity into their everyday lives.

\section{INTRODUCTION}

Physical activity is increasingly recognised as a fundamental prerequisite for maximal health. ${ }^{1} \quad$ Its opposite, physical inactivity, which has been described as a global pandemic, ${ }^{2}$ was estimated to cause $9 \%$ of global premature mortality in 2008 as well as $6 \%$ of

\section{Strengths and limitations of this study}

- Ours is the first study we know of to examine the evidence of interventions to increase commuter cycling, an activity that may potentially integrate physical activity into many people's lives.

- Studies were included of any methodological design with comparison groups and/or preintervention and postintervention data but needed to include cycle commuter outcomes.

- Despite wide variation between prevalence of cycling between countries, robust evidence of what interventions will increase commuter cycling is sparse.

the global burden of coronary heart disease, $7 \%$ of type 2 diabetes, $10 \%$ of breast cancer and $10 \%$ of colon cancer. ${ }^{3}$ This is equivalent to the global burden of mortality caused by tobacco. ${ }^{1}$ There is strong to moderate evidence for a $20-40 \%$ reduction in many longterm conditions including cardiovascular disease, coronary heart disease, stroke, type 2 diabetes, osteoarthritis, breast and colon cancer and depression ${ }^{4}$ as the result of being physically active. Up to $70 \%$ of the National Health Service (NHS) budget is estimated to be spent on long-term conditions. ${ }^{5}$

The WHO and at least 19 countries have issued physical activity guidelines. ${ }^{6}$ However, translating these guidelines into action has proven difficult; increasing technology and proliferation of labour-saving devices including motor-vehicles have increasingly removed physical activity from everyday life, and elite sporting events such as the Olympics or the FIFA football world cup have not encouraged mass participation. ${ }^{7}$

Environmental designs have been shown to increase physical activity, particularly for stair use, ${ }^{8}$ playgrounds and transport to schools. ${ }^{9}$ However, it is possibly unlikely that many will climb the stairs for bouts of $10 \mathrm{~min}$ as recommended by guidelines ${ }^{4}$ or that travel to school will impact significantly on adult behaviour, at least in the short term. Organisations may have a financial interest 
in protecting and promoting the health of their employees, particularly if an intervention is free, but these are likely to only include those employees in organisations that are either large enough and/or are inclined to develop such plans. ${ }^{10}$

As a year-round activity that is integrated into everyday life, active commuting would appear to be one means by which physical activity might be increased and maintained. In the UK, there are some 21.5 million people who undertake a 'regular commute to a fixed onshore location' for whom $64.2 \%$ have journeys under $10 \mathrm{~km}$ and $42.9 \%$ have journeys under $5 \mathrm{~km},{ }^{11}$ a cycling distance considerably less than the $8 \mathrm{~km}$ cited by the British Medical Association (BMA) ${ }^{12}$ that a 'person can easily cover'. While active commuting is largely defined to include both walking and cycling, it is cycling that has been found to be of sufficient intensity to meet the criteria for Health-Enhancing Physical Activity (HEPA), ${ }^{13}$ to require the $4 \mathrm{MJ}(=955 \mathrm{kcal})$ weekly energy expenditure needed to reduce all-cause and cardiovascular mortality $^{14}$ and to improve performance in untrained men and women. Despite this, levels of cycling vary widely from approximately $1 \%$ in Australia, the UK and the USA to $27 \%$ in the Netherlands. ${ }^{15}$

A number of reviews have therefore sought to examine the evidence of how the prevalence of physical activity can be increased through cycling. ${ }^{16-20}$ However, where these reviews seek to identify how to increase the prevalence of cycling, in general this may include cycling for transport, leisure, recreation, health or sport. It may be that commuter cycling-defined following the European Network for Cycling Expertise as journeying for the sake of completing a journey as opposed to a journey that is an end in itself ${ }^{21}$-is more likely to be continued and to have sustainable health gains. Increased commuter cycling may also have the additional benefits of avoiding the external costs of motorised transport including injuries, pollution (including noise pollution) and community severance. ${ }^{22}$ In an age of austerity, commuter cycling has further monetary implications for the individual and their family.

The Government recognises that increasing physical activity requires 'weaving incidental activity into our daily lives' including using bicycles for transport. ${ }^{23}$ This was echoed in the recent NHS Five Year Forward View that there needs to be a 'radical upgrade in prevention and public health' ${ }^{5}$ Policymakers will find implementation of this ambition difficult unless there is good-quality evidence of interventions that have examined evidence of interventions to increase commuter cycling. The nearest such review appears to have been by Yang et al. ${ }^{20}$ While Yang et al sought to determine what interventions are successful in promoting cycling for any purpose, this may not be ideal from a public health perspective. Cycling for sport or leisure need not become habitual in the way that commuting is largely a necessary activity and indeed may increase external costs as people use motorised transport to arrive at a location where sport/ leisure cycling is desirable. The aim of this review therefore was to add to the article by Yang $e t$ al by identifying and analysing interventions designed to increase commuter cycling, for example, that was intended for travel from 'place to place'. The specific review question was therefore: what interventions increase commuter cycling?

\section{METHODS}

\section{Data sources and search strategy}

In October and November 2014, eight databases were searched including Scopus, ERIC, CINAHL, the Cochrane library, Digital Dissertations, Sports Discus, PsycINFO and Web of Science. Scopus is the largest ever bibliographic database and indexes over 20000 titles from science, technology, medicine and the social sciences, is updated daily and contains both the Medline and EMBASE databases. ${ }^{24}$

In each database, a set of core key words were used: cycl* OR bik* OR cycle AND hire OR active and commut* OR active AND travel* OR green AND commut* OR green AND transport* OR green AND travel* OR ecological AND commut* OR ecological AND transport* OR non-motor* OR non-auto. On the returned titles, database-specific filters were then applied to narrow the search. Table 1 presents the original hits in each database on core keywords search and how attrition happened as the database-specific filters were applied.

The final set of titles after applying relevant filters $(n=9825)$ were then imported to RefWorks reference manager software. Duplicates $(n=492)$ were removed to obtain 9333 titles ready for screening.

\section{Study attributes required for inclusion (population, intervention, comparators and study designs) \\ Outcome variable}

Commuter cycling may be affected by a wide range of factors such as urban planning, congestion, safety and perception of safety, pollution, petrol, pricing, etc. ${ }^{25}$ This can lead to the 'inverse evidence law' whereby that which may have the most effect on health is precisely that which is least measured due to methodological considerations. ${ }^{26}$ The application of strict inclusion criteria adopted by Ogilvie et $a l^{17}$ or Yang $e t a l^{20}$ was therefore precluded in favour of the more pragmatic approach adopted by Pucher et al. ${ }^{16}$ To be included, studies needed to report specifically on commuter cycling as a dependent variable (rather than walking and cycling combined) and indicate quantifiable changes in commuter cycling rather than modelling or stated preference studies or other variables that may influence levels of cycling but are not direct measurements such as perceived safety, opinion, confidence on a bicycle or attitude towards active transport. This, however, included a wide range of outcome measure such as changes at an 
Table 1 Search strategy and results

\begin{tabular}{|c|c|c|c|}
\hline Database & $\begin{array}{l}\text { Initial number of hits } \\
\text { with core keywords } \\
\text { search }\end{array}$ & Attrition as database-specific filters was applied & $\begin{array}{l}\text { Final number of hits } \\
\text { after applying all filters }\end{array}$ \\
\hline Scopus & 845 & Filter not used & 845 \\
\hline ERIC & 11847 & $\begin{array}{l}\text { Limit to: academic journals-4879 } \\
\text { Limit to: higher education, postsecondary education, } \\
\text { case studies, intervention, program effectiveness- } \\
1789\end{array}$ & 1789 \\
\hline CINAHL plus & 43324 & $\begin{array}{l}\text { Limit to: academic journals-37 } 745 \\
\text { Limit to: cycling-2414 } \\
\text { Limit to: adult-1359 }\end{array}$ & 1359 \\
\hline Cochrane library & 39218 & Limit to: reviews-377 & 377 \\
\hline $\begin{array}{l}\text { Digital } \\
\text { Dissertations }\end{array}$ & Just over 1 million & $\begin{array}{l}\text { Limit to: scholarly journals-326 } 607 \\
\text { Limit to: American J of PH, Social Research, Health } \\
\text { Affairs-2938 }\end{array}$ & 2938 \\
\hline PsycINFO & 56448 & $\begin{array}{l}\text { Limit to: academic journals-47 } 213 \\
\text { Population-human-11366 } \\
\text { Subject-health, physical activity-196 }\end{array}$ & 196 \\
\hline Sports Discus & 95808 & $\begin{array}{l}\text { Limit to: academic journals-23 } 166 \\
\text { Subject thesaurus term-cycling, exercise, physical } \\
\text { fitness, cyclists, prevention-1494 } \\
\text { Subject-males, comparative studies, young adults, } \\
\text { evaluation, adulthood, women, teenagers, research, } \\
\text { middle age, case studies-615 }\end{array}$ & 615 \\
\hline Web of Science & Just over 1 million & $\begin{array}{l}\text { Limit to: engineering, behavioural sciences, public } \\
\text { environmental occupational health, sports sciences, } \\
\text { healthcare sciences services, sociology-371 } 085 \\
\text { Research domains-restrict to behavioural } \\
\text { sciences, public environmental occupational health, } \\
\text { sports sciences, healthcare sciences services, } \\
\text { sociology, life sciences, biomedicine other topics, } \\
\text { social issues, social sciences other types-194 } 675 \\
\text { Research areas-restrict to behavioural sciences, } \\
\text { public environmental occupational health, } \\
\text { engineering, social sciences other topics, urban } \\
\text { studies, transportation-144 } 459 \\
\text { Limit to: articles-125, } 612 \\
\text { English-114 } 955 \\
\text { Limit to: transportation, urban studies-827 }\end{array}$ & 827 \\
\hline $\begin{array}{l}\text { Total databases } \\
\text { searched=8 }\end{array}$ & $\begin{array}{l}\text { Total initial hits=over } 2 \\
\text { million }\end{array}$ & Total after applying filters $=9825$ & $\begin{array}{l}\text { Total imported to } \\
\text { RefWorks }=9825\end{array}$ \\
\hline
\end{tabular}

aggregate population level, number of days cycling, distance, time taken cycling and time at follow-up.

\section{Eligibility criteria}

To be included in the review, studies needed to include comparison groups and/or preintervention and postintervention data, include adults rather than schoolchildren, include data on cycling rather than aggregated data of walking and cycling, include data relating to commuting to work and be written in English (table 2). All study designs (except correlation studies identifying determinants of commuter cycling) were eligible, as the intention was to capture wider public health interventions, noting that often such evaluations are not limited to robust study designs such as the randomised controlled trials.

\section{Identification of studies}

In level 1 screening, the titles, abstracts and keywords of 9333 non-duplicates were screened according to the criteria set out in table 2 by the lead author (GS). This screening excluded a large number of studies $(n=9267)$, leaving only 66 studies to be retrieved for full-text screening. In level 2 screening, all 66 full texts were screened independently by two authors (GS and SP) by applying the eligibility criteria. Disagreement $(n=2 / 66)$ was settled by asking the opinion of the third author (NKA) and reaching a consensus thereafter. This screening process led to 54 studies not being eligible, and therefore they were excluded from further review. The reasons for exclusion were: correlation studies $(n=16)$; no pre-post data $(\mathrm{n}=11)$; did not provide the outcome 
Table 2 Eligibility criteria

\begin{tabular}{ll}
\hline Inclusion criteria & Exclusion criteria \\
\hline Evaluation studies with comparison groups and/or & Correlation studies (identifying determinants of commuter \\
preintervention and postintervention data & cycling) \\
Adults rather than schoolchildren & No comparison groups or pre-post data available \\
Data relating to commuting to work & Did not provide outcome data in the format needed for this \\
Written in English & review \\
& - Indiscriminate data (eg, has only aggregated data of \\
& walking and cycling) \\
& - Irrelevant data (has data only on other forms of commuting, \\
& eg, walking only or cycling for recreation) \\
& Non-evaluation (eg, editorials, commentaries, opinion pieces) \\
& Others, eg \\
& - Temporal/trend analysis of cycling behaviour \\
& - Reviews of correlation studies \\
& - School children \\
& - Written in a language other than English \\
\end{tabular}

data in the format needed for this review $(n=14)$; non-evaluation articles $(n=4)$; and others $(n=9)$.

A total of 12 studies were thus identified as eligible for full review. Figure 1 depicts a PRISMA diagram of the study identification and inclusion process.

\section{Quality appraisal}

The first author (GS) extracted data on the 12 included studies using a predefined data extraction table, informed by the Centre for Reviews and Dissemination guidelines ${ }^{27}$ and National Institute for Health and Care Excellence $(\mathrm{NICE})^{28}$ (see online supplementary appendix 1). The first author (GS) developed the data extraction table and piloted it by extracting data on one study. This was reviewed by the other two authors before finalising it.

Two authors (GS and NA) then independently applied a quality checklist extracted from NICE's public health guidance methods manual ${ }^{28}$ on $25 \%(n=3 / 12)$ of included studies. This checklist covered several questions enabling the reviewers to judge the quality of each study. A quality rating was also given for all included studies as per the checklist guidelines. There was no disagreement in overall quality ratings between the two reviewers on those 3/12 studies. However, minor disagreement emerged in answering some questions in the checklistwhich was settled by seeking the opinion of the third author and reaching a consensus. Then the first author completed quality assessment on the remaining studies. Of the 12 included studies, 1 study $^{29}$ was given a "++" rating (ie, study designed to minimise risk); 3 studies ${ }^{30-32}$ were given a "+" rating (ie, potential sources of bias not addressed in the study or not clear from the way the study was reported); and 8 studies were given a "-" rating (ie, study with significant sources of bias).

\section{Data analysis}

The data were analysed qualitatively, considering four key attributes underlying the robustness and generalisability of included evidence: (1) the population size where the claimed effect was observed/measured; (2) the robustness of the comparator; (3) the extent to which the interventions being evaluated were able to increase commuter cycling prevalence and (4) the robustness of the study design. The information retrieved through data extraction tables, coupled with assessments in the quality appraisal checklist, was used to inform each of the above four domains. As interventions were a mixture of environmental and individualfocused/group-focused measures, no meta-analysis of data was attempted. As such, we chose to present the findings as a narrative synthesis.

\section{RESULTS}

\section{Study characteristics}

Of the 12 included studies, 6 were from the UK, 2 from Australia, 1 each from Sweden, Ireland, New Zealand and the USA. Of those, two studies were randomised control trials (RCT) ${ }^{29} 31$ and the remainder preintervention and postintervention studies. The majority of studies $(n=7)$ evaluated individual-based or group-based interventions and the rest environmental interventions. Table 3 includes the characteristics of included studies.

\section{Individual or group interventions}

The two RCTs included in this review evaluated individual interventions that were based on provision of written information or advice and a bicycle by health professionals to encourage cycling. Mutrie et $a l,{ }^{31}$ a Scottish study, aimed to increase active commuting among 295 employees at three workplaces in Glasgow. Hemmingsson et $a l^{29}$ a Swedish study, intended to increase levels of physical activity through a support programme involving three aims (awareness raising, countering and helping relationships) in obese women. The Scottish study was based on the transtheoretical model of behaviour change providing self-help materials to 


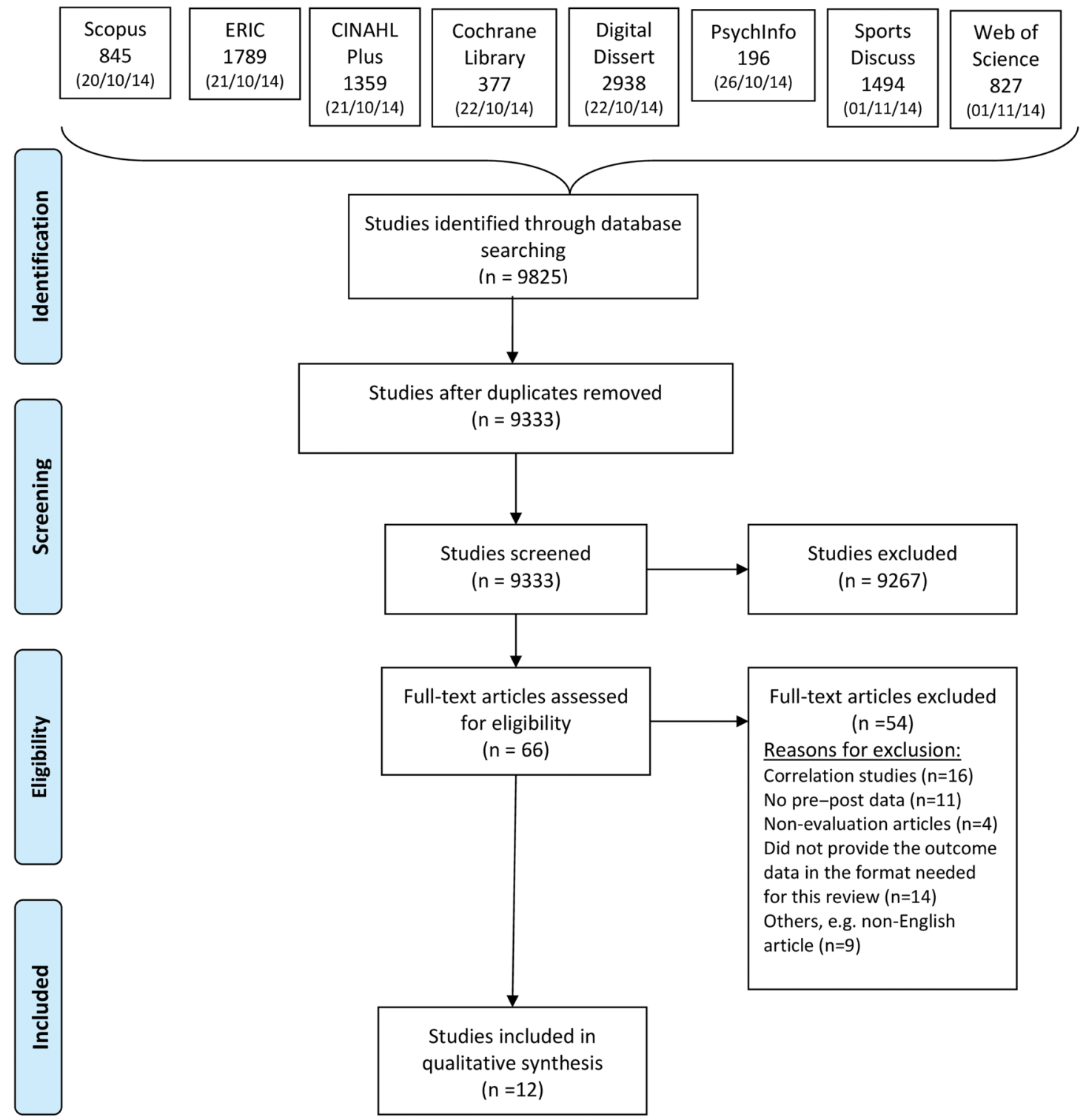

*informed by Moher D, Liberati A, Tetzlaff J, Altman DG, The PRISMA Group (2009). Preferred Reporting Items for Systematic Reviews and Meta-Analyses: The PRISMA Statement. PLoS Med 6(6)

Figure 1 PRISMA diagram of the study identification and inclusion process (Digital Dissert, Digital Dissertations).

people either thinking about active commuting (contemplators) or irregular commuters (preparers). Follow-up at 6 months found that while 18\% more participants in the intervention group (compared with the control group) moved to a higher stage of active commuting behaviour, the significant difference was largely attributed to walking and not cycle commuting. Only 18 people (of the 295) were cycling with no difference between the intervention and control groups. The Swedish study, however, reported an effective intervention. They compared two different support programmes to increase physical activity through active commuting. The intervention group received physician meetings, physical activity prescriptions, group counselling and bicycles compared with the control group which received low-intensity group support and pedometers at 6 months. The mean proportion of intervention group participants $(\mathrm{n}=60)$ commuting with a bicycle at least once a week during months $2-18$ was $29.4 \%$ compared with $8 \%$ in the control group.

Workplace travel plans that seek to encourage active travel programmes have been promoted as having advantages to the employee (health) and employer (lower absenteeism). These may include 'bike to work' (BTW) initiatives. Three studies examined the effects of such programmes in England (Bristol), ${ }^{33}$ Australia ${ }^{34}$ and New 


\begin{tabular}{|c|c|c|c|c|c|c|c|}
\hline $\begin{array}{l}\text { Serial } \\
\text { number }\end{array}$ & Study & Country/setting & Intervention & Study design & Time period & Sample size & Effect \\
\hline 1 & $\begin{array}{l}\text { Brockman and } \\
\text { fox }^{33}\end{array}$ & $\begin{array}{l}\text { England (University of } \\
\text { Bristol) }\end{array}$ & Workplace travel plan(s) & $\begin{array}{l}\text { Preintervention and } \\
\text { postintervention }\end{array}$ & $\begin{array}{l}\text { Surveys from } \\
1998 \text { to } 2007\end{array}$ & $1950-2829$ & $\begin{array}{l}\text { Percentage usually cycling to work } \\
\text { increased from } 7 \% \text { to } 12 \% \text { but was not } \\
\text { significant }\end{array}$ \\
\hline 2 & $\begin{array}{l}\text { Hemmingsson } \\
\text { et } a \text { f }^{9}\end{array}$ & Sweden/community & $\begin{array}{l}\text { Support programme } \\
\text { (awareness raising, } \\
\text { countering and helping } \\
\text { relationships) }\end{array}$ & $\mathrm{RCT}$ & 18 months & 120 & $\begin{array}{l}\text { Proportion of participants cycling }>2 \mathrm{~km} / \\
\text { day was } 38.7 \% \text { (OR } 7.8 \text { ) }\end{array}$ \\
\hline 3 & Mutrie et $a{ }^{\beta 1}$ & $\begin{array}{l}\text { Scotland/Hospital } \\
\text { Trust, Health Board } \\
\text { and University }\end{array}$ & $\begin{array}{l}\text { Workplace; self-help pack } \\
\text { including maps, activity } \\
\text { diary, safety accessories }\end{array}$ & $\mathrm{RCT}$ & 6 months & $\begin{array}{l}295 \text { people } \\
\text { identified as } \\
\text { thinking about } \\
\text { active travel }\end{array}$ & No effect \\
\hline 4 & Telfer et $a \beta^{36}$ & Australia (Sydney) & Cycle proficiency training & $\begin{array}{l}\text { Preintervention and } \\
\text { postintervention }\end{array}$ & 2 months & 113 & $\begin{array}{l}\text { No difference in mean frequency or } \\
\text { duration of cycle trips }\end{array}$ \\
\hline 5 & O'Fallon ${ }^{35}$ & $\begin{array}{l}\text { New Zealand- } \\
\text { number of workplaces }\end{array}$ & $\begin{array}{l}\text { Number of workplace } \\
\text { interventions }\end{array}$ & $\begin{array}{l}\text { Preintervention and } \\
\text { postintervention }\end{array}$ & 12 months & 3825 & $\begin{array}{l}675 \text { respondents to cycle question-112 } \\
\text { cycled less }(16.6 \%), 347(51.4 \%) \text { about } \\
\text { the same and } 216(32.0 \%) \text { more }\end{array}$ \\
\hline 6 & $\begin{array}{l}\text { Johnson and } \\
\text { Margolis }^{37}\end{array}$ & $\begin{array}{l}\text { London-community } \\
\text { setting }\end{array}$ & Cycle training & $\begin{array}{l}\text { Preintervention and } \\
\text { postintervention }\end{array}$ & 12 months & 130 & $\begin{array}{l}\text { Number of days cycled to work in the last } \\
\text { week increased from } 0.66 \text { to } 1.33\end{array}$ \\
\hline 7 & Caulfield $^{39}$ & Ireland-Dublin & Whole city approach & $\begin{array}{l}\text { Preintervention and } \\
\text { postintervention }\end{array}$ & 5 years & $\begin{array}{l}\text { Dublin population } \\
1.2 \text { million }\end{array}$ & $\begin{array}{l}\text { Percentage of cyclists increased from } 4 \% \\
\text { to } 5 \%(20588 \text { to } 26670)\end{array}$ \\
\hline 8 & $\begin{array}{l}\text { Rose and } \\
\text { Marfurt }^{34}\end{array}$ & Australia (Victoria) & Ride To Work Day & $\begin{array}{l}\text { Preintervention and } \\
\text { postintervention }\end{array}$ & 5 months & 5577 & $\begin{array}{l}27 \% \text { of first-time riders still cycling to } \\
\text { work after } 5 \text { months }\end{array}$ \\
\hline 9 & $\begin{array}{l}\text { McCartney } \\
\text { et } a \beta^{\beta}\end{array}$ & Scotland-Glasgow & Building a bridge & $\begin{array}{l}\text { Preintervention and } \\
\text { postintervention }\end{array}$ & $2007-2010$ & $\begin{array}{l}216897 \text { people } \\
\text { living south of city } \\
\text { centre }\end{array}$ & $\begin{array}{l}47.5 \% \text { increase in the number of cyclists } \\
(n=\text { approximately } 400)\end{array}$ \\
\hline 10 & Goodman et $a \beta^{\beta 0}$ & $\begin{array}{l}\text { England-Cycling } \\
\text { Cities and Towns } \\
\text { initiative ( } 12 \text { locations) }\end{array}$ & Whole city approaches & $\begin{array}{l}\text { Preintervention and } \\
\text { postintervention }\end{array}$ & 2008-2012 & 1266337 & $\begin{array}{l}0.69 \text { percentage point increase in cycling } \\
\text { to work in intervention towns, compared } \\
\text { with matched towns }\end{array}$ \\
\hline 11 & Goodman et $a^{\beta^{2}}$ & $\begin{array}{l}\text { England ( } 3 \text { cities/ } \\
\text { towns) }\end{array}$ & $\begin{array}{l}\text { Changes in walking and } \\
\text { cycle infrastructure }\end{array}$ & $\begin{array}{l}\text { Preintervention and } \\
\text { postintervention }\end{array}$ & 2010-2012 & $\begin{array}{l}22500 \text { (residents } \\
\text { within } 5 \mathrm{~km} \text { of } \\
\text { projects }\end{array}$ & $\begin{array}{l}\text { At } 2 \text { year follow-up, } 18 \% \text { of people who } \\
\text { knew about project reported transport } \\
\text { cycling compared with } 7 \% \text { of full sample }\end{array}$ \\
\hline 12 & Krizek et $a{ }^{40}$ & US-Minneapolis & $\begin{array}{l}\text { Changes in cycle } \\
\text { infrastructure }\end{array}$ & $\begin{array}{l}\text { Preintervention and } \\
\text { postintervention }\end{array}$ & $1990-2000$ & 4855 & $\begin{array}{l}0.493 \text { percentage point increase in } \\
\text { bicycle modal share }\end{array}$ \\
\hline
\end{tabular}


Zealand. ${ }^{35}$ Results were again mixed; in Bristol, the University travel survey indicated a non-significant rise in the cycle commuting modal share from $7 \%$ in 1998 to $11.8 \%$ following the implementation of a workplace travel plan. In Australia, in 2004, 5577 people registered for the Ride to Work Day event of whom baseline data was received from $1952(35 \%)$. Of these, 17\% indicated that they had not cycled to work before the event. At 5 months postevent, $27 \%$ of first-timers were still cycling to work (defined as at least once a week) compared with $67 \%$ of those who had been cycling to work before the event. In New Zealand, 40 organisations were originally recruited to the 'Bike Now' programme of which 27 (675 workers) remained in the programme at 1 year. Of these, $112(16.6 \%)$ of 675 respondents indicated that they were cycling less, $347(51.4 \%)$ about the same and $216(32.0 \%)$ more. None of the above included a control group.

Two studies examined the effect of cycling training on cycling to work. Results were not consistent; in Sydney, a telephone 1-week recall interviews found no difference in either duration or frequency of cycling at 2 months (including number of days cycled to work) following a cycling proficiency training programme $(\mathrm{n}=110)$ although statistically significant increases in those who did not cycle before the course were found.$^{36}$ In London, 3-month postintervention questionnaires found that the mean number of days cycled to work increased from 0.66 to 1.33 in the past week. ${ }^{37}$ Neither study included a control group. Loss to follow-up from the London study was high (104 responses from 471 participants).

\section{Environmental interventions}

Environmental interventions were either a relatively small single intervention (eg, the construction of a bridge $^{38}$ ) or a larger programme such as the English Cycling Cities and Towns (CCT) initiative that targeted 12 cities and towns with some 2.7 million residents over 3 years $^{30}$ or several policies taken together on cycle commuter prevalence. ${ }^{39}$

The opening of a bridge in Glasgow was associated with a $47.5 \%$ increase in the number of cyclists entering the city centre from the South with almost no change in numbers of cyclists crossing other bridges. Some of this change may have been accounted for by road works associated with the construction of the M74 which was not controlled for. ${ }^{38}$

The English CCT programme aimed to increase cycling through capital and revenue investment provided through competitive tendering to the respective CCTs. Changes in cycle commuting between 2001 and 2011 in the CCTs were compared with changes in matched towns using a 'difference in difference' analysis. Controls were either statistically matched towns, towns that had applied unsuccessfully for funding or a non-London national comparison group (all nonintervention urban areas outside London with a population of over 30000$)$. The 'difference in difference' analysis indicated that compared with matched towns, cycling to work in the intervention towns increased by 0.69 percentage points with larger differences in differences compared with the unfunded comparison group (1.02 percentage points) and the national comparator (1.23 percentage points). Although seemingly small in effect, the size of the sample population in the 12 towns (1 266337 in the 2011 census) indicates that the absolute percentage change in cycle commuting $(0.97 \%)$ may have a large public health significance. ${ }^{30}$

In Ireland, the Department of Transport set targets of increasing cycling from 2\% of journeys in 2009 to $10 \%$ by 2020. In Dublin, commuter cycling was hypothesised to result from financial incentives (tax-free loans to purchase cycles), infrastructure change (traffic calming, cycle lanes including segregated lanes), promotional events such as Bike week (family rides, removing traffic from streets, repair clinics and promotion talks), a shared bike scheme and publication of the first design standards for cycling in Ireland. ${ }^{39}$ Census data indicated that results were equivocal; cycle modal share fell from 6\% in 1996 to $4 \%$ in 2002 and 2006 but had risen to 5\% in 2011. In Cork, cycle modal share fell from $2 \%$ in 1996 to 1\% from 2002 onwards, whereas in Galway it fell from $3 \%$ in 1996 to $2 \%$ from 2002. However, it is not clear as to what extent the 2008 financial crisis in Ireland might have affected the results.

In three UK cities/towns, traffic-free infrastructure (a main project plus feeder routes) were evaluated for their effects on residents living within $5 \mathrm{~km}$ of the respective projects. ${ }^{32}$ A total of 22500 survey packs were distributed to which 3516 people replied of whom $53 \%$ and $43 \%$ provided data at the 1-year and 2-year followups, respectively (excluding those who had moved house). Respondents were asked if they had cycled on the infrastructure for six journey purposes including commuter cycling. At the 2-year follow-up, $18 \%$ of people who knew about the project reported transport cycling compared with $7 \%$ of the full sample. However, the multivariate statistical analysis presented in the study provided data on infrastructure use for any purpose rather than commuter cycling.

One US study ${ }^{40}$ assessed the effects of transport/cycle infrastructure on cycle commuting. Cycle commuter modal share increased in central Minnesota (from 2.8\% to $3.3 \%$ at the University of Minnesota $(\mathrm{n}=4855))$ and Minneapolis (from 0.788 to $0.841, \mathrm{n}=21111$ ) where cycle facilities had been implemented or improved, compared with the suburbs where cycle commute share fell from $0.335 \%$ to $0.279 \%$ ( $\mathrm{n}=9016)$. This study, however, was not immune to other external influences and, as acknowledged, the 'Lance Armstrong effect' may have been present at the time.

\section{DISCUSSION}

This review improves our understanding as to what interventions are likely to increase commuter cycling, an 
activity that may potentially integrate physical activity into many people's lives. There is wide agreement that increased population levels of physical activity would make substantial improvements to health. Intuitively, the potential for commuter cycling to at least partially meet this need is large. In Europe, most car journeys are less than $5 \mathrm{~km}$, most people can cycle, the financial costs are small, and for the individuals, financial savings would be made against the cost of motorised or public transport. There is also evidence of where this has been achieved -in countries such as Holland, Germany and Denmark, a substantial proportion of journeys are by bicycle, including those by people aged $65+{ }^{15}$ Despite all this, this review highlights how little robust research evidence exists on what may increase commuter cycle prevalence in low cycling nations.

Of the two RCTs included in the review, only one found evidence of effectiveness but in a select population of obese women-which may therefore lack external validity for the wider population. The second RCT found no evidence of effectiveness even in people assessed, through the transtheoretical model of behaviour change, as at least ready to begin to change. Other individualbased or group-based studies that assessed the effectiveness of interventions on populations opting into programmes found either no or small effect sizes, again indicating a lack of evidence for their applicability at a population level. This review also found that many studies did not include relevant control groups and had high rates of loss to follow-up, indicating a high risk of bias and that the effect of external factors cannot be discounted.

Wider environmental interventions perhaps have the potential to have a greater though more dilute effect over a greater proportion of the population. Evaluation of environmental interventions includes several methodological issues that have been well documented, ${ }^{41}$ including defining what may be described as the denominator population (working population, working population from a particular area or the whole population). As included studies did have some of these issues present in their design, there is a clear paucity of evidence of effectiveness. NICE guidance acknowledges that a range of factors may be important in helping or restricting people from cycling ${ }^{42}$ and that may reflect the challenge of rigorous evaluation in this field. However, it is also noted that even small changes at a population level can have significant effects and therefore important implications for population health. For example, the 0.69 percentage point differential effect of an environmental intervention in England implies that over 8000 people started commuter cycling, following the implementation of CCT. Therefore, environmental interventions, despite showing small effect sizes, appear to have more public health significance than individual-based/group-based interventions, as they will reach out to many more people (though often harder to define populations) to encourage integration of physical activity into everyday life via commuter cycling.
This review has its own limitations which stem largely from major weaknesses of the included studies. Evaluation of real-world interventions where variables cannot be controlled by researchers can be challenging, as found in the case of all included studies. Studies suffered from high dropout rates (almost all studies had substantial loss to follow-up) and used numerous measures of outcome variables (commuter cycling) which were difficult to compare meaningfully. Most studies suffered from the lack of robust comparison groups, leading to a less robust alternative of measuring outcomes preintervention and postintervention instead. Significant aspects of potential bias in those studies therefore cannot be ruled out. Put together, this review was limited to a narrative synthesis of evidence rather than a more robust quantitative meta-analysis.

Finally, the paucity of high-quality evidence found in this review may highlight an important methodological issue related to the review itself. As noted by Pucher et $a l^{16}{ }^{16}$ interventions that might affect cycling prevalence are many and varied but few may be published. By restricting its focus to commuter cycling, this review may have excluded a number of interventions that increased general and commuter cycling. Given the potential for health gain, the lack of robust evidence on effective interventions may be disappointing for policymakers. More research is therefore needed to fill in this important gap as well as to further our understanding as to how lessons learnt in high cycling-prevalent countries can be applied to other countries.

\section{CONCLUSION}

Despite its potential to increase health, there is little robust evidence of effective interventions to increase commuter cycling even at a subpopulation level. Many studies lack appropriate controls, their external validity to the wider population remains unclear, and they have high rates of loss to follow-up-all indicating a high risk of bias. Wider environmental interventions that make cycling conducive appear to reach out to hard to define but larger populations. This could mean that environmental interventions, despite their small positive effects, have greater public health significance than individualbased or group-based measures because those interventions encourage a larger number of people to integrate physical activity into their everyday lives. More research is needed to establish how prevalence of commuter cycling can be increased.

Acknowledgements The authors would like to thank Professor Christina Victor and Dr Geraldine Barrett for their critical comments earlier in the review process. They hugely benefited from the comments made by the two referees who reviewed the manuscript on first submission.

Contributors This study is a part of GS doctoral thesis. GS conceptualised, designed and executed the study with significant inputs from NKA and SP throughout. GS prepared the first draft of this manuscript, which was commented on and revised by NKA and SP. All authors have read and approved the manuscript. 
Funding This research received no specific grant from any funding agency in the public, commercial or not-for-profit sectors.

Competing interests None declared.

Provenance and peer review Not commissioned; externally peer reviewed.

Data sharing statement No additional data are available.

Open Access This is an Open Access article distributed in accordance with the Creative Commons Attribution Non Commercial (CC BY-NC 4.0) license, which permits others to distribute, remix, adapt, build upon this work noncommercially, and license their derivative works on different terms, provided the original work is properly cited and the use is non-commercial. See: http:// creativecommons.org/licenses/by-nc/4.0/

\section{REFERENCES}

1. Das $P$, Horton R. Rethinking our approach to physical activity. Lancet 2012;380:189-90.

2. Kohl HW, Craig CL, Lambert EV, et al. The pandemic of physical inactivity: global action for public health. Lancet 2012;380:294-305.

3. Lee IM, Shiroma EJ, Lobelo F, et al. Effect of physical inactivity on major non-communicable diseases worldwide: an analysis of burden of disease and life expectancy. Lancet 2012;380:219-29.

4. Department of Health. Start Active, Stay Active. A report on physical activity for health from the four home countries' Chief Medical Officers. 2011.

5. National Health Service. Five Year Forward plan. 2014.

6. IHRSA. Physical Activity Guidelines International. http://download. ihrsa.org/publicpolicy/Physical_Activity_Guidelines_INTL.pdf

7. Hallal PC, Bauman AE, Heath GW, et al. Physical activity: more of the same is not enough. Lancet 2012;380:190-1.

8. Foster $\mathrm{C}$, Hillsdon $\mathrm{M}$. Changing the environment to promote health-enhancing physical activity. J Sports Sci 2004;22:755-69.

9. Reynolds R, McKenzie S, Allender S, et al. Systematic review of incidental physical activity community interventions. Prev Med 2014;67:46-64.

10. Hosking J, Macmillan A, Connor J, et al. Organisational travel plans for improving health. Cochrane Database Syst Rev 2010;3:CD005575.

11. Office for National Statistics. 2011 Census Analysis-Distance Travelled to Work, 2014.

12. British Medical Association. Healthy Transport=Healthy Lives. 2010.

13. Oja P, Vuori I, Paronen O. Daily walking and cycling to work: their utility as health-enhancing physical activity. Patient Educ Couns 1998:33:S87-94.

14. Shephard RJ. Is active commuting the answer to population health? Sports Med 2008;38:751.

15. Pucher J, Buehler R. Making cycling irresistible: lessons from the Netherlands, Denmark, and Germany. Transport Rev 2008;28.

16. Pucher J, Dill J, Handy S. Infrastructure, programs, and policies to increase bicycling: an international review. Prev Med 2010;50(Suppl 1):S106-25.

17. Ogilvie $\mathrm{D}$, Egan $\mathrm{M}$, Hamilton $\mathrm{V}$, et al. Promoting walking and cycling as an alternative to using cars: systematic review. $B M J$ 2004;329:763-6.

18. Fraser SD, Lock K. Cycling for transport and public health: a systematic review of the effect of the environment on cycling. Eur $J$ Public Health 2011;21:738-43.

19. Krizek KJ, Forsyth A, Baum L. Walking and Cycling International Literature Review. Final Report. 2009.
20. Yang L, Sahlqvist S, McMinn A, et al. Interventions to promote cycling: systematic review. BMJ 2010;341:c5293.

21. Aldred R. A Matter of Utility? Rationalising Cycling, Cycling Rationalities. Mobilities. 2014. doi:10.1080/17450101.2014.935149

22. Mindell JS, Watkins SJ, Cohen JM. Health on the Move 2. Policies for health promoting transport. Stockport: Transport and Health Study Group, 2011.

23. Public Health England. Everybody active, every day. An evidence based approach to physical activity. Public Health England, 2014.

24. Brunel University. Databases Webpage. Site accessed 1st November 2014.

25. Heinen E, van Bee B, Kees M. Commuting by bicycle: an overview of the literature. Transport Rev 2010;30:59-96.

26. Ogilvie D, Egan M, Hamilton V, et al. Systematic reviews of health effects of social interventions: 2 . Best available evidence: how low should you go? J Epidemiol Community Health 2005;59:886-92.

27. Centre for Review and Dissemination. Systematic Reviews: CRD's Guidance for Undertaking Reviews in Health care. 2009.

28. NICE. Methods for the development of NICE public health guidance (third edition): Appendix F Quality Appraisal Checklist-quantitative intervention studies. 3rd edn. National Institute for Health and Care Excellence, 2012

29. Hemmingsson E, Uddén J, Neovius M, et al. Increased physical activity in abdominally obese women through support for changed commuting habits: a randomized clinical trial. Int J Obes 2009;33:645-52.

30. Goodman A, Panter J, Sharp SJ, et al. Effectiveness and equity impacts of town-wide cycling initiatives in England: a longitudinal, controlled natural experimental study. Soc Sci Med 2013;97: 228-37.

31. Mutrie N, Carney C, Blamey A, et al. "Walk in to Work Out": a randomised controlled trial of a self help intervention to promote active commuting. J Epidemiol Community Health 2002;56:407-12.

32. Goodman A, Sahlqvist S, Ogilvie D. Who uses new walking and cycling infrastructure and how? Longitudinal results from the UK iConnect study. Prev Med 2013;57:518-24.

33. Brockman R, Fox KR. Physical activity by stealth? The potential health benefits of a workplace transport plan. Public Health 2011;125:210-16.

34. Rose G, Marfurt $\mathrm{H}$. Travel behaviour change impacts of a major ride to work day event. Transportation Res Part A 2007;41:351-64.

35. O'Fallon C. Bike Now: Exploring methods of building sustained participation in cycle commuting in New Zealand. Road and Transport Research 2010;19(2).

36. Telfer B, Rissel C, Bindon J, et al. Encouraging cycling through a pilot cycling proficiency training program among adults in central Sydney. J Sci Med Sport 2006;9:151-6.

37. Johnson R, Margolis S. A review of the effectiveness of adult cycle training in Tower Hamlets, London. Transport Policy 2013;30:254-61.

38. McCartney G, Whyte B, Livingston M, et al. Building a bridge, transport infrastructure and population characteristics: explaining active travel into Glasgow. Transport Policy 2012;21:119-25.

39. Caulfield B. Re-cycling a city-examining the growth of cycling in Dublin. Transportation Res Part A 2014;61:216-226.

40. Krizek K, Barnes G, Thompson K. Analyzing the effect of bicycle facilities on commute mode share over time. J Urban Plann Dev 2009;135:66-73.

41. Petticrew M, Cummins S, Ferrella $C$, et al. Natural experiments: an underused tool for public health? Public Health 2005;119:751-7.

42. National Institute for Health and Clinical Excellence (NICE). Walking and cycling: local measures to promote walking and cycling as forms of travel or recreation 2012. 